Niğde Ömer Halisdemir Üniversitesi Mühendislik Bilimleri Dergisi
Niğde Ömer Halisdemir University Journal of Engineering Sciences
ISSN: 2564-6605
Araştırma / Research

\title{
Experimental study for artificial neural network (ANN) based prediction of electric energy production of diesel engine based cogeneration power plant
}

\author{
Dizel motorlu kojenerasyon santralinin elektrik enerjisi üretiminin yapay sinir \\ ağı (YSA) ile tahmini üzerine deneysel çalışma
}

\author{
Andaç Batur Çolak ${ }^{1, *}($ \\ ${ }^{3}$ Niğde Ömer Halisdemir University, Mechanical Engineering Department, 51240, Niğde, Turkey
}

\begin{abstract}
In this study artificial neural network (ANN) has been developed in order to estimate the electricity production of cogeneration power plant, which produces a total of $11.52 \mathrm{MW}$ electric power, consisting of two V type and 12 cylinders each of which is $5.760 \mathrm{~kW}$ diesel engines running with heavy fuel oil no 6. In the ANN which was developed for the estimation of electric power generation of cogeneration, power plant $(W)$, Time period $(t)$, working hours $(h)$, fuel consumption $(m)$ and internal power consumption $(W p)$ values were used as input variables. After evaluating the performance of different ANNs, an ANN, consisting of one hidden layer and 10 neurons, was considered to be the most ideal one. As a result of the comparison with experimental data, it is concluded that this model estimates the electricity generation values of the cogeneration power plant with an $R$-value of 0,99073 and mean square error $4.734 e-8$
\end{abstract}

Keywords: Cogeneration, Diesel engine, Power plant, Electricity consumption, Artificial Neural Network

\section{Introduction}

With the increase in population, the developing industrial industry has brought more energy needs. The studies of the International Energy Agency (IEA) show that world electricity demand in 2040 will increase by $80 \%$ compared to 2012 [1]. The types of electric power plants are vital in meeting the increasing demand for electricity. Consumption of electricity where it is produced is one of the most preferred and useful methods since it eliminates the factors causing the decrease in efficiency such as energy losses in transmission lines. In the industrial area, cogeneration power plants are frequently preferred as high-efficiency energy production system in case there is a need for electrical power as well as heat power (hot water, steam etc.). It is possible to define the cogeneration system as a system where electricity and heat energy are produced simultaneously using a single fuel source. The cogeneration system is used in domestic applications as well as in industrial systems which need electricity and heat energy [2]. Because of the high financial savings due to the high fuel efficiency obtained from the system, it is seen that legal subsidies are applied in many countries for cogeneration systems which are frequently preferred owing to their environmental advantages [3-5]. The cogeneration system, which can also be known as combined heat and power (CHP) plant, is not a new concept. At the end of the 1800 s, when steam was the major energy source in the industry, the concept of cogeneration emerged

\begin{abstract}
Özet
Bu çallşmada iki adet V tipi 12 silindirli dizel motordan oluşan ve her biri $5.760 \mathrm{~kW}$ olmak üzere toplam $11.52 \mathrm{MW}$ elektrik enerjisi üreten kojenerasyon enerji santralinin elektrik üretiminin tahmin edilmesi için yapay sinir ă̆ (YSA) geliştirilmiştir. 6 no'lu fuel oil ile çalışan kojenerasyon enerji santralinin elektrik enerjisi üretiminin (W) tahmini için geliştirilen YSA'da, zaman (t), çalışma saatleri (h), yakıt tüketimi (m) ve iç tüketim $(W p)$ değerleri giriş değişkenleri olarak kullanılmıştır. Farklı YSA'ların performansi değerlendirildikten sonra, bir gizli katman ve 10 nörondan oluşan YSA en ideal model olarak değerlendirilmiştir. Deneyse verilerle yapılan karşılaștırma sonucunda, bu modelin kojenerasyon enerji santralinin elektrik üretim değerlerini $0,99073 R$ değeri ve 4.734 e8 MSE ile tahmin edebileceği sonucuna varılmıștır.
\end{abstract}

Anahtar kelimeler: Kojenerasyon, Dizel motor, Enerji sanrali, Elektrik tüketimi, Yapay Sinir A ğ 1

as a result of replacing mechanical driven systems with electrically driven systems and replacing steam-driven beltpulley mechanisms with electricity and motors [6, 7]. Demand for cogeneration systems is increasing day by day due to the ability to produce the required electricity and thermal energy from a single fuel source such as oil or natural gas and with a high efficiency ratio. The energy efficiency of cogeneration systems can reach up to $80 \%$ compared to conventional electricity generation systems [8]. The high fuel efficiency values in electrical and thermal energy production are the main advantages of the cogeneration system. Because waste heat from conventional systems is converted into useful thermal energy in cogeneration systems, a smaller amount of fuel is needed to produce the equivalent amount of energy as conventional systems (turbine, steam boilers, etc.) to produce electrical and thermal energy in the cogeneration system $[9,10]$. As they reduce the impact of greenhouse gases by up to $50 \%$ with their technical and economic advantages, the environmental advantages of cogeneration systems reach considerable proportions $[11,12]$. Although they have many different applications, the most common application in cogeneration power plants is the power plants established with internal combustion engines and open cycle gas turbines. Heavy fuel diesel power plants, a low-grade oil refinery product, operate on diesel fuel, which is relatively inexpensive than other types. This technology, which can produce hundreds of megawatts of energy, stands out with

\footnotetext{
* Sorumlu yazar / Corresponding author, e-posta/e-mail: andacbaturcolak@hotmail.com (A. B. Colak) Geliş / Recieved: 18.06.2020 Kabul/ Accepted: 01.10.2020 Yayımlanma / Published: 15.01.2021 doi: $10.28948 /$ ngumuh.754411
} 
the advantages of being able to be installed quickly in less than twelve months [13]. According to their capacity, diesel engine cogeneration power plants can be classified into three main categories as low capacity $(15-1000 \mathrm{~kW})$, medium capacity ( $1-6 \mathrm{MW})$ and high capacity (over $6 \mathrm{MW})$. The diesel cogeneration power plant has four available waste heat sources: exhaust gas, engine jacket cooling water, lubricating oil cooling water and charge air cooling water. Exhaust gases from diesel cogeneration power plants have a substantial sum of thermal energy that can be used to recover waste heat. The heat recovered from the exhaust gas is generally considered to be hot water or steam production. The resulting recycling energy can be used for an assortment of process needs, heating and cooling applications [14]. In many studies on energy efficiency in the literature, the advantages of cogeneration plants have been scientifically proven [15-18]. In the literature, many studies have been done on diesel engines and cogeneration power plants.

While some of the studies on diesel engines have carried out analyzes on the second law of thermodynamics [19, 20], some researchers have studied the effects of diesel engine parameters on performance and emission values [21-23]. Previous studies on cogeneration power plants have mostly focused on the efficiency of power plant and exergy analysis. Ust et al. [24] in their study on a gas turbine regeneration system, optimizing the external performance criteria of the power plant, demonstrated the advantages of this method. In his study for cogeneration power plants, Ertesva [25] evaluated the external comparisons of efficiency indicators for cogeneration power plants and consequently stated that external improvements were achieved to a limited extent by several energy-based efficiency indicators. Khaliq and Han [26] analyzed the heat and power system of a gas turbine cogeneration plant using the first and second laws of thermodynamics. The case study on a diesel engine-operated cogeneration plant was also carried out with only the first laws in mind [27]. In the management of the electrical energy system, it is of excessive prominence to estimate the production capacities of the power plants operating in the grid. In cases where the total capacity of electrical energy that the power plants in the system can produce is lower than the amount of electrical energy required, power outages begin to occur. Power cuts in the system, especially unplanned power outages, bring technical and economic problems. Considering that the sudden power outages, stopping in industrial processes, deterioration of the materials in the production system, interruption of production and re-commissioning, serious losses are observed [28]. Unstable operation of power generation systems with interruptions can also cause malfunctions in mechanical systems and generator units. In view of all these reasons, accurate estimation of the generation capacity of an electric power plant is of great importance both in terms of providing the required energy stably and sustainably and in the management of the electricity grid [29].

In the literature, many studies have been conducted on the estimation of the electricity generation capacity of power plants. Since data mining techniques are used in the methods used in such studies, it is possible to estimate the electricity generation capacities only for local cases in the database. In the data mining technique, the structure of the database can be examined, and estimated values can be obtained [30]. In the absence of the data required to create a model in the database, errors can also occur in the estimation results. For example, since the decrease in the performance of an electrical power plant will increase as the working hours increase, long-term data of the power plant are needed to estimate the performance decline using long-term data for performance estimation by data mining technique. In the absence of sufficient data, the estimation results will not be accurate. It is seen that this method is frequently used in the literature due to the advantage that the characteristics and performance factors of the power plant can be evaluated simultaneously [31-33]. One of the methods for estimating the desired values is the artificial intelligence (AI) thanks to the algorithms developed using the obtained data. In the literature, artificial intelligence applications for estimating the performance and production values of power plants are frequently encountered. Smrekar et al. [34] and Tunckaya et al. [35] used statistical data and artificial neural network (ANN) model in their study on estimating the performance of coal-fired power plants. Boksteen et al. [36] used the Bayesian calibration model to estimate the power plant performance, while Tüfekci [37] preferred the machine learning model developed with long-term data to estimate the performance of combined cycle power plants. Many different studies have been made on the estimation of performance and production values of cogeneration power plants by ANN. Optimization of power plant parameters and development of ANN to achieve efficiency increase [38-41], modeling of the manners of power plant components such as steam boiler and turbine with ANNs [42-46], development of ANN for estimation of thermal efficiency and air pollution [47-51], optimization of power plant load distribution [52, 53], power plant production according to demands [54] are some examples of ANN studies on cogeneration power plants by researchers.

In this study, an ANN model has been developed in order to predict electrical energy production values of a diesel engine cogeneration power plant. However, many applications of ANNs in different areas are also included in the literature [55]. Although there are various studies in the literature on cogeneration power plants, there is no study on estimating the electrical energy production values of diesel engine cogeneration power plants using ANNs. This study is important in that it aims to fill this gap in the literature.

\section{Description of cogeneration power plant}

The cogeneration power plant investigated in this study was established to meet the electricity, hot water and steam needs of five different textile factories. The cogeneration power plant has two MAN brand diesel engines of type $12 \mathrm{~V} 32 / 40$, each of which can produce $5760 \mathrm{~kW}$ of power. $12 \mathrm{~V} 32 / 40$ refers to the 12 is the number of cylinders, V engine type (Vee engine), 32 cylinders bore (cm) and 40 is the piston stroke $(\mathrm{cm})$. In Figure 1, cross-sectional view of the V32/40 diesel engine, in Figure 2 and Table 1, main dimensions of MAN 12V32/40 diesel engine are given [56]. 


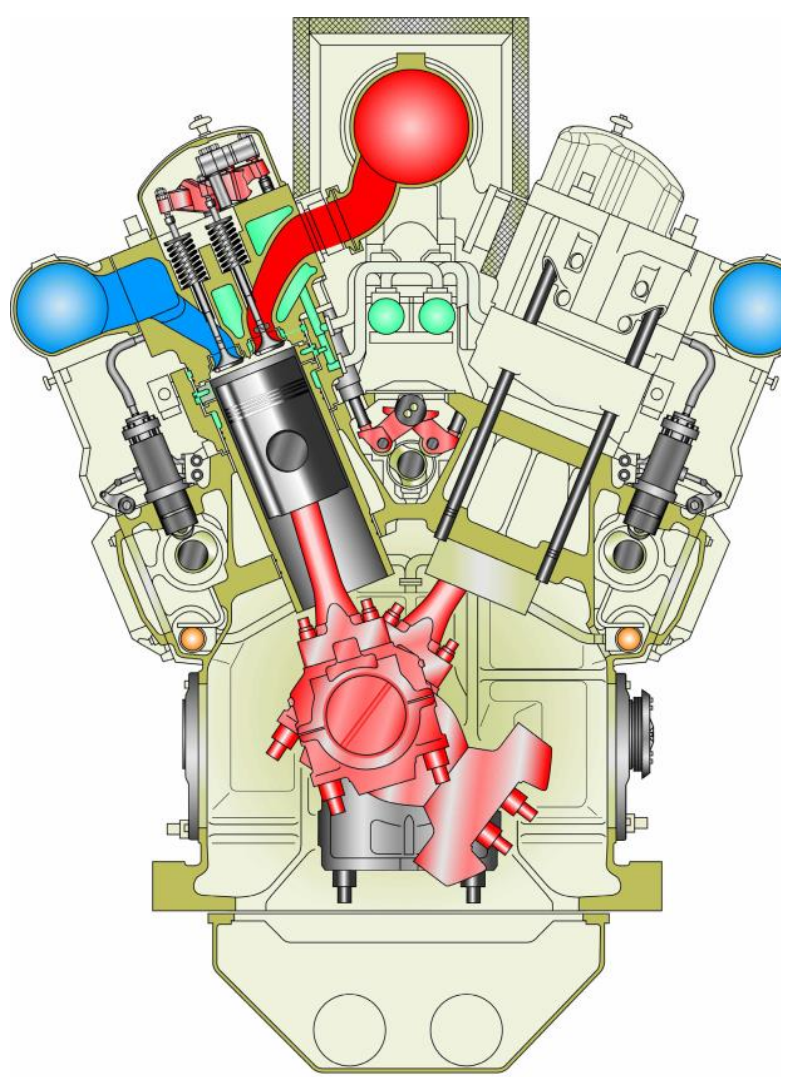

Figure 1. MAN 12V32/40 diesel engine cross section view on coupling side

In the calculations carried out for the cogeneration power plant, which has a total capacity of $11.52 \mathrm{MW}$, the data of one unit was used because the values of both diesel engines were the same. Heavy fuel oil No:6 is used as fuel in the cogeneration power plant. Although the purpose of using this type of fuel, which is also considered as heavy fuel, is its economic advantage compared to other types of fuel, operational difficulties due to the components contained in the fuel content (necessity of using fuel separator, maintenance requirements due to mechanical equipment contamination, yield reduction, etc.) can also be evaluated as disadvantages. The technical characteristics of the fuel used are given in Table 2 .

Table 1. Main dimensions of MAN 12V32/40 diesel engine

\begin{tabular}{cccccc}
\hline $\begin{array}{c}\mathrm{A} \\
(\mathrm{mm})\end{array}$ & $\begin{array}{c}\mathrm{B} \\
(\mathrm{mm})\end{array}$ & $\begin{array}{c}\mathrm{C} \\
(\mathrm{mm})\end{array}$ & $\begin{array}{c}\mathrm{H} \\
(\mathrm{mm})\end{array}$ & $\begin{array}{c}\mathrm{W} \\
(\mathrm{mm})\end{array}$ & $\begin{array}{c}\text { Weight } \\
(\text { tons })\end{array}$ \\
\hline 6.475 & 4.215 & 10.690 & 4.795 & 3.370 & 98
\end{tabular}

In the cogeneration power plant, hot water and steam production are integrated with electricity generation, and all three energy types are transmitted to the enterprises to meet the electricity and process needs of five different power plants. Exhaust excavation at a temperature of approximately $520{ }^{\circ} \mathrm{C}$ enters the boiler and helps to produce a total of 4.5 $\mathrm{t} / \mathrm{h}$ of steam at a pressure of 6 bar and a temperature of 165 ${ }^{\circ} \mathrm{C}$. The process of removing the corrosive gases contained in the feed water fed to the steam serpentines in the boilers and reaching them to a temperature of $102{ }^{\circ} \mathrm{C}$ before the boiler is carried out by means of degasser. The schematic diagram of the cogeneration power plant is given in Figure 3 [57].

In the cogeneration power plant, hot water and steam production are integrated with electricity generation, and all three energy types are transmitted to the enterprises to meet the electricity and process needs of five different power plants. Exhaust excavation at a temperature of approximately $520{ }^{\circ} \mathrm{C}$ enters the boiler and helps to produce a total of 4.5 $\mathrm{t} / \mathrm{h}$ of steam at a pressure of 6 bar and a temperature of 165 ${ }^{\circ} \mathrm{C}$. The process of removing the corrosive gases contained in the feed water fed to the steam serpentines in the boilers and reaching them to a temperature of $102{ }^{\circ} \mathrm{C}$ before the boiler is carried out by means of degasser.

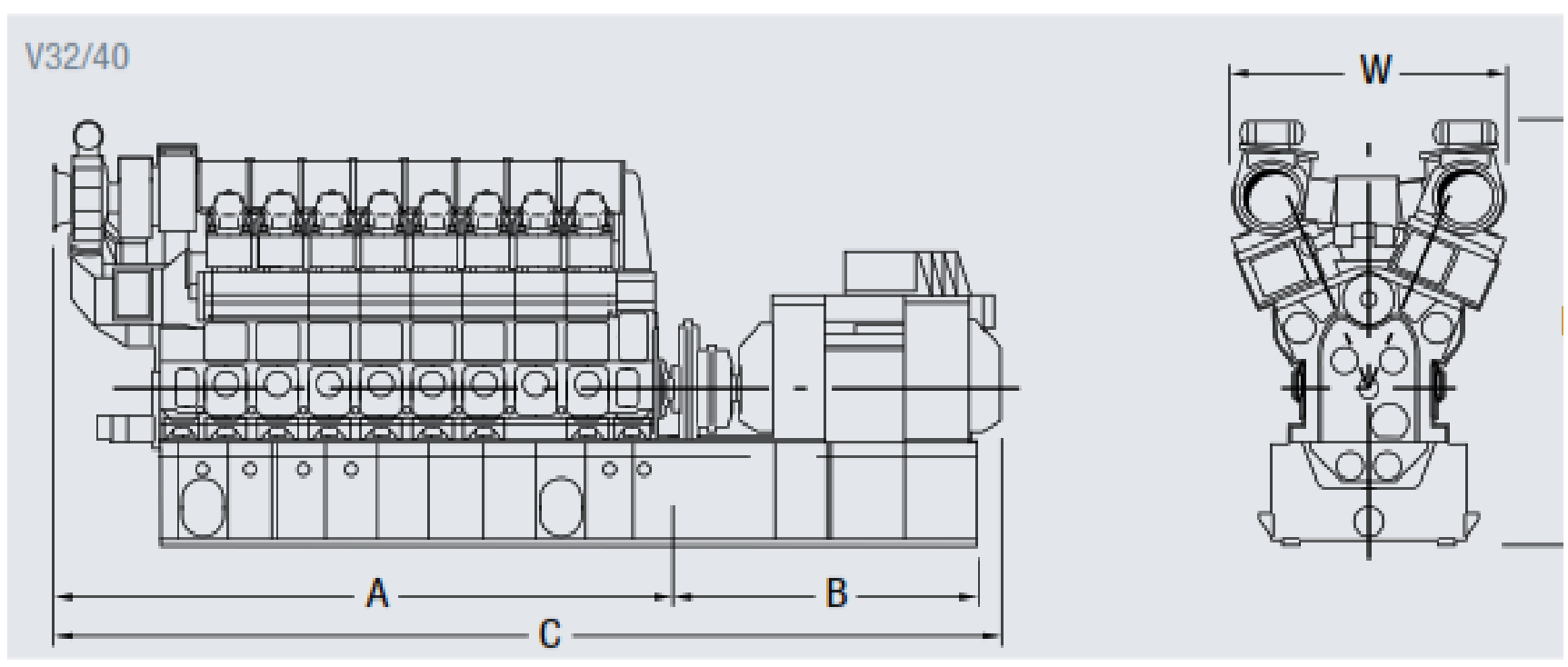

Figure 2. Main dimensions of MAN 12V32/40 diesel engine 
The schematic diagram of the cogeneration power plant is given in Figure 3 [57]. The system in cogeneration power plant; diesel engine, exhaust gas turbine, compressor, heat recovery heat exchangers, charge air cooler, oil cooler, cooling tower, cooling tower heat exchanger and five circulation pumps. As a result of the combustion in the fourstroke diesel engine, the rotational movement of the crankshaft is converted to electrical energy by means of the generator (alternator). The first movement to diesel engines is given by 30 bar compressed air produced by the piston start air compressor.

Table 2. HFO technical characteristics

\begin{tabular}{lc}
\hline \multicolumn{2}{c}{ Heavy Fuel No:6 Typcial Specifications } \\
\hline Ca (weight\%) & $86.5-90.2$ \\
H (weight\%) & $9.5-12.0$ \\
S (weight\%) & $8.51-7.68$ \\
Viscosity (CSt @3 $\left.38^{\circ} \mathrm{C}\right)$ & $260-750$ \\
BS\&W (\%) & $0.05-2.0$ \\
HHV (BTU/LB) & $17410-18990$ \\
\hline
\end{tabular}

When the diesel engine starts, the exhaust gas flow resulting from combustion gives a rotational motion to the exhaust gas turbine. With the rotational movement of the air compressor connected to the same shaft, the compressed air required for the combustion reaction is sent to the cylinder. The entire exhaust gas turbine and air compressor unit, which is connected to the same charge and is integrated into a single case, is called a turbocharger. The charge air, which reaches high temperatures after the compressor, is gradually cooled in the charge air cooler using HT then LT water and then sent to the cylinder. The exhaust gas exiting the diesel engine first enters the turbocharger unit and gives the turbine movement.

After leaving the turbocharger, it enters the waste heat boilers and turns the hot water fed into the serpentines into steam. The steam produced is transferred from the waste heat boilers to the steam tank and then to the enterprises. LT provides water, oil cooling and charge air cooling. HT water, which has a higher thermal capacity, cools the engine, and at the same time, warm water from the engine is obtained by means of heat recovery heat exchanger with a capacity of 140 $\mathrm{t} / \mathrm{h}$ and $85{ }^{\circ} \mathrm{C}$. Information about the cogeneration power plant system is given in Table 3 [57].

\section{Cogeneration power plant data analysis}

In this study, which has been carried out in order to estimate the electrical energy production of the cogeneration power plant with ANN, the production values of the power plant for five-years (60-months) have been used. Time, working hours, internal power consumption and fuel consumption values were used as input variables. Monthly working hours of $5.760 \mathrm{~kW}$ diesel engine were recorded during the 60-month period on which the study was based. Working hours of the cogeneration power plant may vary according to months. The reason is that the downtime of the power plant due to breakdowns, maintenance and the downtime of the plants where energy is supplied. The cogeneration power plant worked for a total of 32.106 hours, with an average of 535,1 hours per month, ranging from 334 to 657 hours per month during the 60 -month period of the study. The graph of the operating hours of the cogeneration power plant in the 60-month period is given in Figure 4.

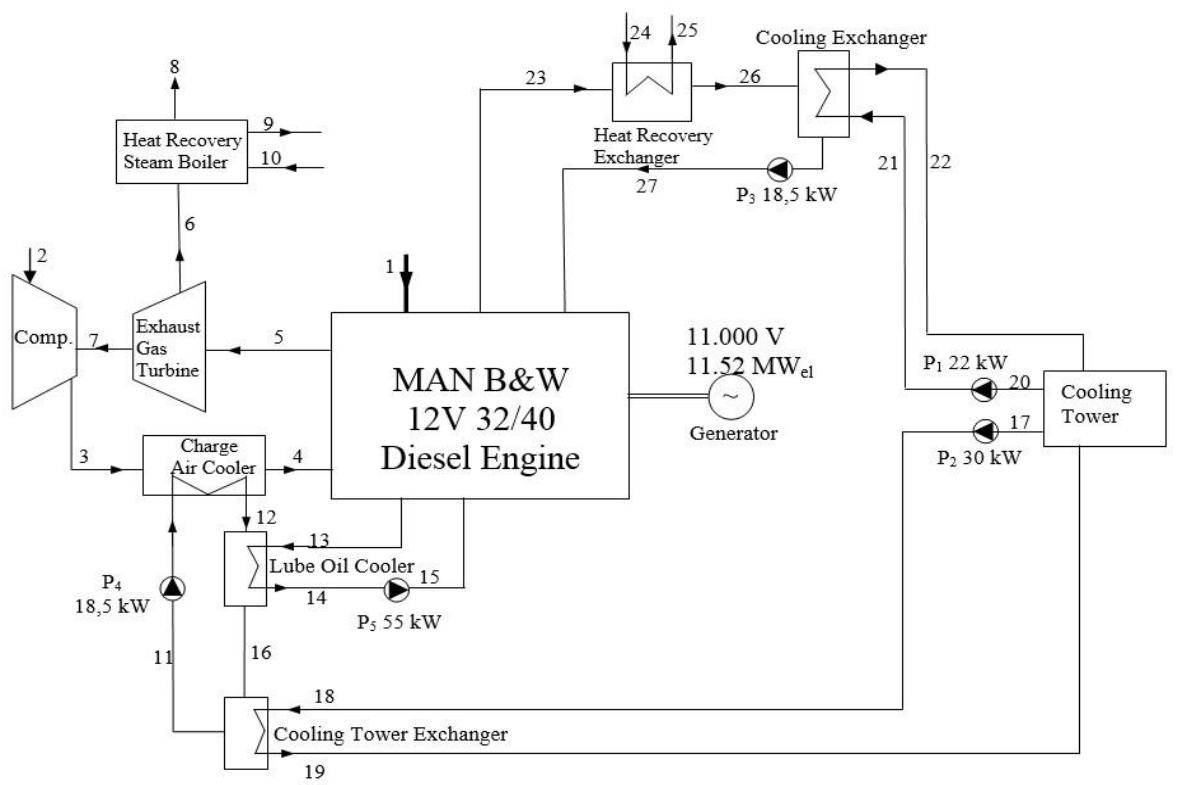

Figure 3. Schematic diagram of the cogeneration power plant 
Table 3. Values about cogeneration power plant

\begin{tabular}{|c|c|c|c|c|}
\hline No & Flow identification & $\begin{array}{c}\mathrm{m} \\
(\mathrm{kg} / \mathrm{h})\end{array}$ & $\begin{array}{c}\mathrm{T} \\
\left({ }^{\circ} \mathrm{C}\right) \\
\end{array}$ & $\begin{array}{c}\mathrm{P} \\
(\mathrm{kPa})\end{array}$ \\
\hline 1 & Inlet fuel & 0.318 & 125 & 640 \\
\hline 2 & Air inlet (before compressor) & 11 & 27 & 2 \\
\hline 3 & Air (after compressor) & 11 & 225 & 300 \\
\hline 4 & Air ( for charge) & 11 & 55 & 300 \\
\hline 5 & Exhaust gas (before turbine) & 11.31 & 520 & - \\
\hline 6 & Exhaust gas (after turbine) & 11.31 & 330 & 2.5 \\
\hline 7 & Shaft & - & - & - \\
\hline 8 & Exhaust gas & 11.31 & 210 & 2.5 \\
\hline 9 & Steam for factory & 12.50 & 165 & 600 \\
\hline 10 & Make up water & 12.50 & 102 & 700 \\
\hline 11 & LT water (inlet) & 31.67 & 35 & 260 \\
\hline 12 & LT water (outlet) & 31.67 & 40 & 260 \\
\hline 13 & Lube oil (inlet) cooler & 38.88 & 75 & 420 \\
\hline 14 & Lube oil (outlet) cooler & 38.88 & 65 & 420 \\
\hline 15 & Inlet lub oil & 38.88 & 65 & 420 \\
\hline 16 & Charge air (inlet) water for CT HE & 31.66 & 50 & 260 \\
\hline 17 & Water (outlet) CT & 31.94 & 30 & 300 \\
\hline 18 & LT (Inlet) water & 31.94 & 30 & 300 \\
\hline 19 & LT (Outlet) water & 31.94 & 40 & 300 \\
\hline 20 & Heat Recovery (Engine) Exchanger & 31.66 & 25 & 300 \\
\hline 21 & HT (Inlet) water & 31.66 & 25 & 300 \\
\hline 22 & HT (Outlet) water & 31.66 & 25 & 300 \\
\hline 23 & Heat Recovery (Outlet) & 20 & 90 & 420 \\
\hline 24 & Water (Return line) & 38.88 & 70 & 600 \\
\hline 25 & Water (to factory) & 38.88 & 90 & 550 \\
\hline 26 & HT Exchanger (inlet) & 20 & 70 & 420 \\
\hline 27 & HT Exchanger (outlet) & 20 & 80 & 420 \\
\hline
\end{tabular}

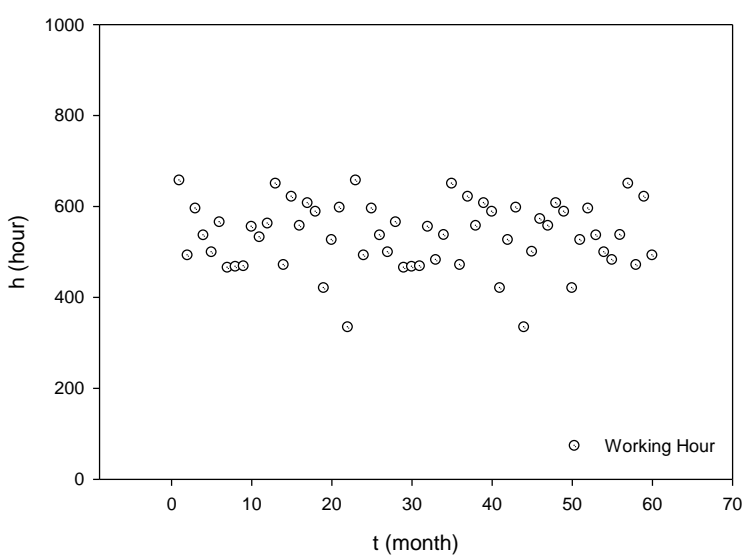

Figure 4. Operating hours of the cogeneration power plant

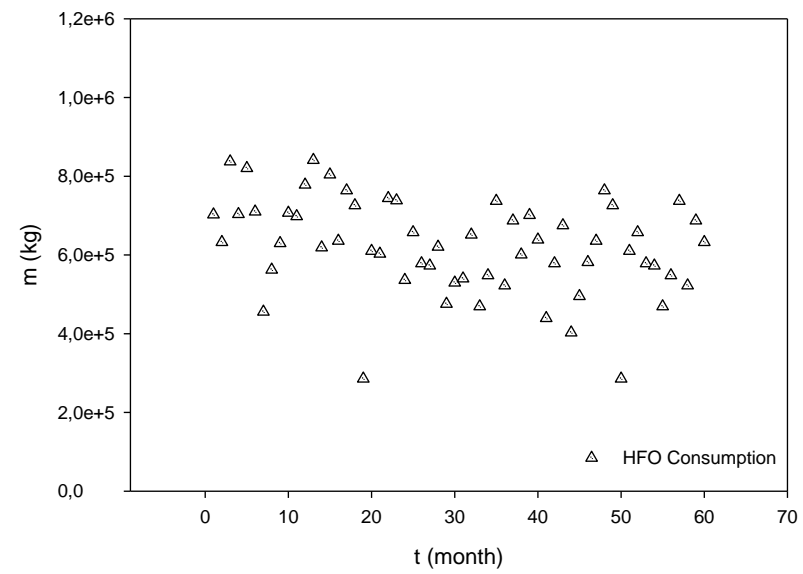

Figure 5. Fuel consumed in the cogeneration power plant

The graph of the amount of fuel consumed in the cogeneration power plant operating with heavy fuel oil no:6 over a period of 60 months is shown in Figure 5. In this process, between $285.698 \mathrm{~kg}$ and $841.073 \mathrm{~kg}$ fuel was consumed in the power plant and a total of $37.729 .499 \mathrm{~kg}$ of fuel consumption was realized, with an average of 621.325 $\mathrm{kg}$ per month. The reason for the difference in fuel consumption in the power plant is that the working hours differ each month due to the circumstance that the power plant stops owing to the reasons explained previously.

During the operation of the cogeneration power plant, the equipment such as the fuel module, instrument air compressors, separators, lubrication and cooling water pumps, water treatment system and lighting consume electrical energy. Such consumption in the power plant is expressed as the internal consumption or internal need of the power plant. During the 60-month period in which the study data were taken, the total electricity consumption of 6.305.137 kWh was realized for the internal consumption of the cogeneration power plant ranging from $73.350 \mathrm{kWh}$ to $132.062 \mathrm{kWh}$, with an average of $105.086 \mathrm{kWh}$ per month. Figure 6 indications the graph of the internal consumption of the cogeneration power plant.

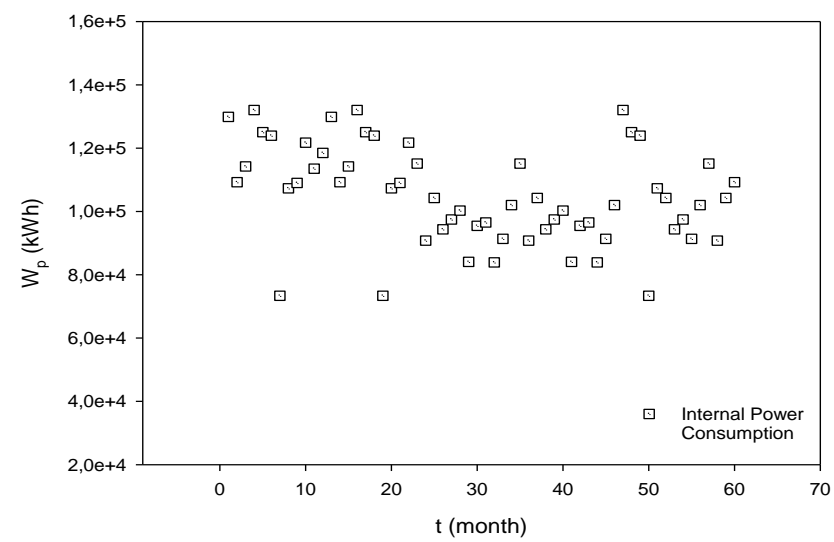

Figure 6. Internal consumption of the cogeneration power plant 


\section{Artificial Neural Network}

One of the ideal methods for estimating the electricity generation of a cogeneration power plant is the use of ANN. ANNs generally be made of three separate layers: input, hidden and output layers. The input layer is where data is received and behaves like a self-determining variable. The sum of input layer neurons unwavering by the structure of the model depends on the sum of arguments. The other layer, the hidden layer, does not characterize any impression and only affords midway results to calculate output values and calculates the sum of each unit in ANNs by multiplying the weights corresponding to the input values. The sum of the calculated morals is then mapped to the output value using a transfer function [58]. Multi-layer perceptron (MLP) model is one of the most widely used ANN models. In ANNs developed using this model, prediction of nonlinear mathematical equations can be performed at high performance levels.

The multi-layer perceptron model includes an input layer, as a minimum one hidden layer, and an output layer, each layer being entirely linked to the next layer. These bonds between layers consist of neurons, the basic processing element. Neurons are identified by bias (b), weights (w) and a transfer function (f). The weight values fixed using a unsystematic number generator are multiplied by the input values of each neuron, and the values obtained are added to each other and to the bias value. The neuron value is calculated as follows:

$$
Y_{j}=f\left(\sum_{i=1}^{n} W_{j, i} x_{i}+b_{j}\right)
$$

Where $\mathrm{Y}$ is the neuron output, $\mathrm{n}$ is the number of neurons that connect to the jth neuron, and $\mathrm{x}$ is the incoming signals.

In the ANN developed using multi-layer perception, the process of determining the appropriate weight and bias for learning the functional relationship between input and output is entitled "training". One of the most efficient and common algorithms used for training ANN is feed-forward backpropagation (FF-BP) algorithm. In this algorithm, information processing is performed in the feed-forward phase and this process is propagated from the input layer to the output layer. The errors between the predicted and actual data are calculated in the backward processing stage and sent back to the input layer to adjust the biases and weights. This process continues step by step until the error rate in the ANN is minimized. In estimating the energy production values of cogeneration power plants, since the operating hours of the plant, the amount of fuel consumed and the internal consumption values of the plant are the parameters that affect the result, these three parameters are defined as the input value. The output parameter is the amount of electrical energy manufactured by the cogeneration power plant, and this value is obtained in the one-dimensional output layer. The basic structure and configuration topology of the developed ANN is presented in Figure 7 and 8, respectively.

In the developed ANN model, the sum of hidden layers and neurons are the most imperative factors that unswervingly affect the predictive performance [59]. The presence of a small number of hidden layers and neurons in an ANN causes the ANN to be incorrectly trained, and the accuracy of prediction is low. With the purpose of minimize the guesstimate error, the excessive number of neurons is not an accurate approach. It is important to optimize the data to be used in the ANN in order to obtain the ideal estimation accuracy. In this study, feed-forward back-propagation multi-layer perceptron ANN has been developed by using data obtained from a diesel engine cogeneration power plant, and this model has been used to estimate the electricity generation values of the cogeneration power plant. In the ANN developed using 60 data, the data were separated into three groups as training, testing and validation. $42(70 \%)$ of the 60 data were used for the training phase, 9 (15\%) for the test phase and $9(15 \%)$ for the validation phase. The values obtained from the mean square error (MSE) and R equations given in Equation (2) and (3), respectively, were chosen as norms for the optimization and performance analysis of the developed ANN.

$$
\begin{aligned}
& \text { MSE }=\frac{1}{N} \sum_{i=1}^{N}\left(\mathrm{~W}_{\exp (\mathrm{i})}-\mathrm{W}_{\mathrm{ANN}(\mathrm{i})}\right)^{2} \\
& \mathrm{R}=\sqrt{1-\frac{\sum_{\mathrm{i}=1}^{\mathrm{N}}\left(\mathrm{W}_{\exp (\mathrm{i})}-\mathrm{W}_{\mathrm{ANN}(\mathrm{i})}\right)^{2}}{\sum_{\mathrm{i}=1}^{\mathrm{N}}\left(\mathrm{W}_{\exp (\mathrm{i})}\right)^{2}}}
\end{aligned}
$$

Where $\mathrm{N}$ is the number of data points, $\mathrm{W}_{\exp }$ is the experimental production value of the cogeneration power plant, and $\mathrm{W}_{\mathrm{ANN}}$ is the production value obtained from the ANN model. The flow chart of this ANN with 10 neurons is presented in Figure 9.

\section{Results and discussion}

In this study, a single hidden layer feed-forward multilayer perceptron method was chosen as an ANN modeling, and Levenberg-Marquardt backpropagation algorithm, which is one of the most proper models for training ANN, was preferred. As transfer functions of hidden and output layers, Tangent sigmoid (Tan-Sig) and linear (Purelin) functions are selected respectively.

The Tan-Sig transfer function and purelin are presented in Equation (4) and (5)

$$
\begin{gathered}
f(x)=\frac{1}{1+\exp (-x)} \\
\operatorname{purelin}(x)=x
\end{gathered}
$$

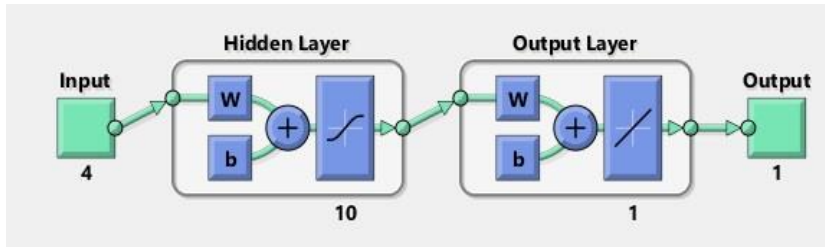

Figure 7. Basic structure of the ANN 


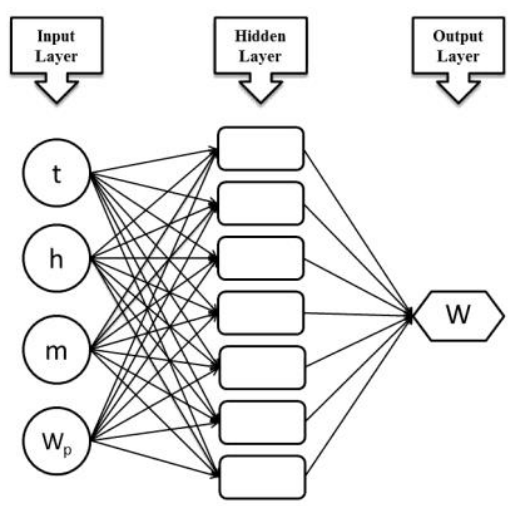

Figure 8. Configuration topology of the ANN

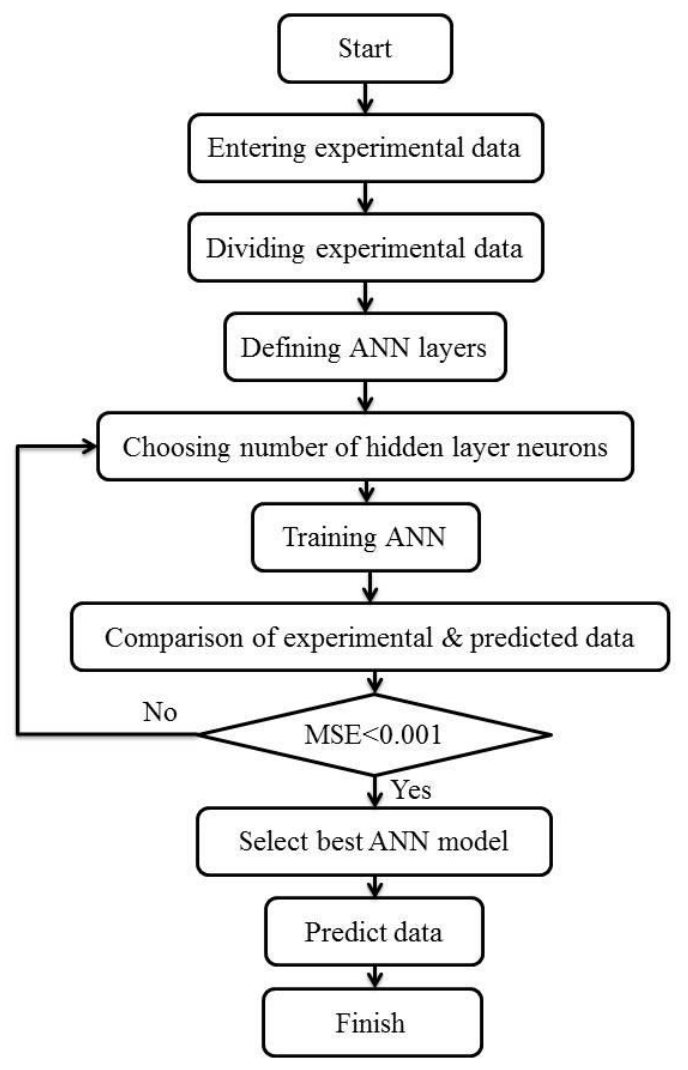

Figure 9. The flow chart of the ANN

In Figure 10, the deviation between the values obtained from the cogeneration power plant and the values obtained from the ANN is plotted. As can be seen in Figure 10, when the training phase of the ANN starts, the high MSE value decreases with increasing periods (epoch). It means that the training stage of the developed ANN model is premeditated acceptably. According to the graph, the MSE rate drops continuously and it is the best result with the lowest MSE value of 27112400562 immediately after 5 iterations. The reason that the ANN achieves the ideal result with the minimum MSE value with a low iteration like 5 is an indication that the data optimization used in the experiment set is done in an ideal way. Figure 11 shows the training status of the ANN model. As shown in Figure 11, the errors were repeated 6 times after epoch 6 and stopped at epoch 11 . This error showed that the over-matching of the repeated data starting from the 6th epoch is very good. Thus, the fifth epoch was chosen as the base, but their weights were chosen as final weights. Furthermore, due to the errors repeated six times before the process is stopped, the validation process is equal to 6. Figure 12 shows the error histogram of the training, validation and testing of the ANN. The distribution of the error distribution around the zero line indicates that the designed ANN can estimate the electrical energy production of the cogeneration power plant with an ideal accuracy rate. Figure 13 appearances the assessment of the experimental results with the data used for training the ANN.

The fact that the training data located on the compatibility line is compatible with the experimental data and the R-value obtained as 0.99586 is an indication that the training process of the ANN is finalized with high accuracy and precision. Figure 14 shows the comparison of tentative data with the data used for testing the ANN.

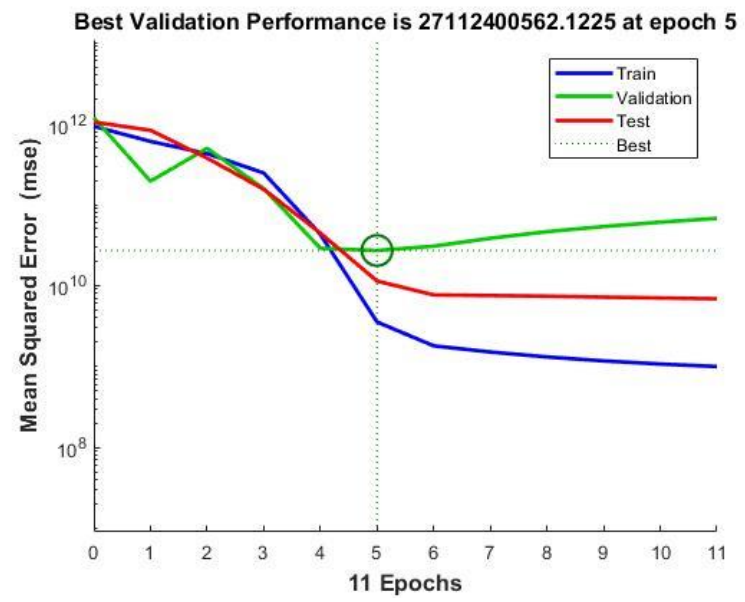

Figure 10. Performance chart of artificial neural network

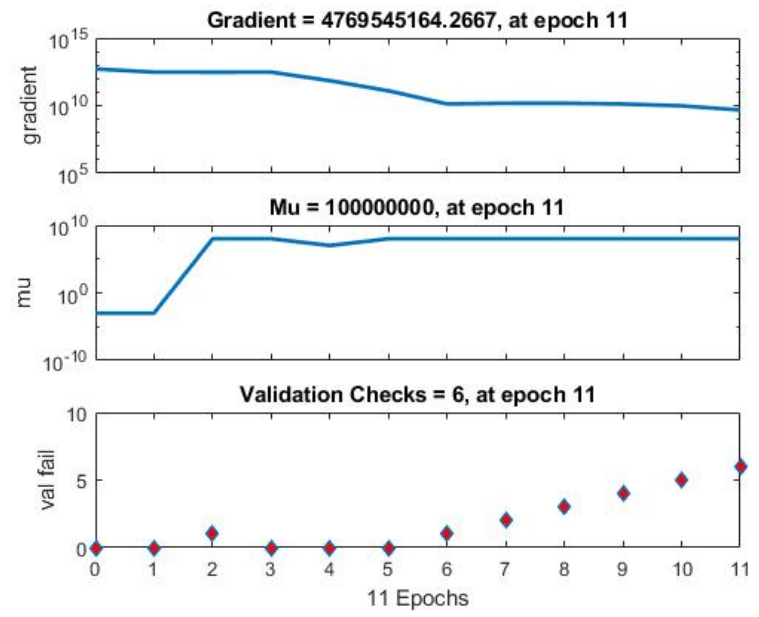

Figure 11. Training status of artificial neural network model

The performance of the test data is important in assessing the suitability and performance of the ANN. The position of the test data close to the equality line and the R-value of the 
test data, which is 0.97918 , can be interpreted as the ideal performance of the improved ANN. Figure 15 shows the validation outcomes of the ANN. The proximity of the validation data to the equality line is indicative of the proper modeling of the ANN. It can be seen that the R-value for the validation results is 0.99227. All the data of the ANN, designed with 60 tentative data, are shown in Figure 16. As can be seen from the graph, all data points obtained from the ANN are located very close to the equality line. This closeness of the data points to the compatibility line indicates that the developed ANN model is capable of generated electrical energy from the cogeneration power plant; time, working hours, fuel consumption and internal power consumption of the plant. The R-value for all ANN results is 0.99073. The performance values of the ANN developed for the purpose of estimating the electricity generation values of the cogeneration power plant are given in Table 4 and Figure 17. The electrical energy production values of the cogeneration power plant are associated with the data obtained from the ANN developed with experimental data. The results have shown that the ANN can accurately predict the electrical energy generation of the cogeneration power plant based on four different input variables. Figure 18 shows the comparison of the values obtained from the ANN with the production values of the cogeneration power plant.

Table 4. ANN performance values

\begin{tabular}{lcccc}
\hline Data Set & MSE & MoD $(\%)$ & $R$ & $\begin{array}{c}\text { Number of } \\
\text { Data }\end{array}$ \\
\hline Train & $3.48 \mathrm{E}-03$ & $-0,65$ & 0.99586 & 42 \\
Test & $5.69 \mathrm{E}-03$ & $-1,02$ & 0.97918 & 9 \\
Validation & $5.64 \mathrm{E}-04$ & 0,06 & 0.99227 & 9 \\
All & $4.48 \mathrm{E}-04$ & $-0,61$ & 0.99073 & 60 \\
\hline
\end{tabular}

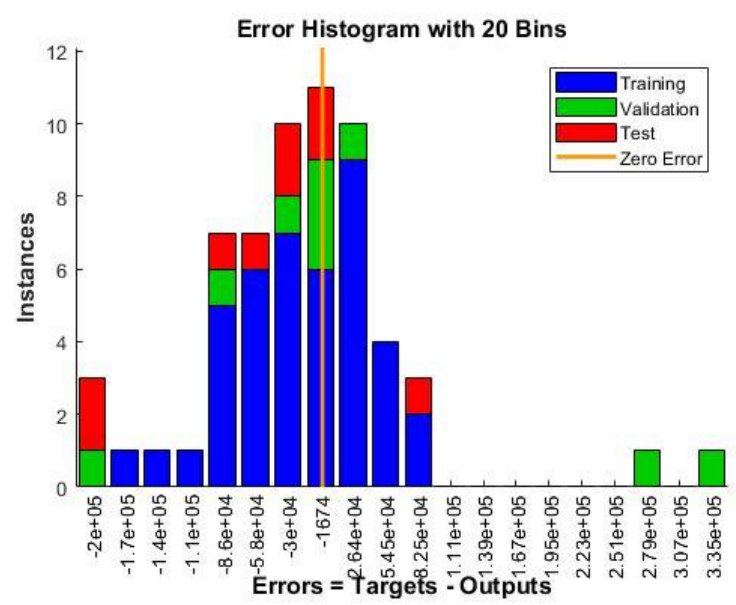

Figure 12. Error histogram

One of the methods used to evaluate the performance of the developed ANN is a standard deviation analysis. The values obtained from the ANN were compared with the electrical energy generation values of the cogeneration power plant, and the deviation values realized for each value were calculated. In the graph given in Figure 19, the electric energy generation values of the cogeneration power plant are placed on the x-axis, and the production values obtained from the ANN developed on the y-axis are placed. The positioning of the data points around the equality line is an indication that the developed ANN accurately predicts the electrical energy generation values of the cogeneration power plant. The deviation between the output values of the ANN and electrical energy generation values of the cogeneration power plant was calculated using the theoretical correlation given in Equation (6) [60].

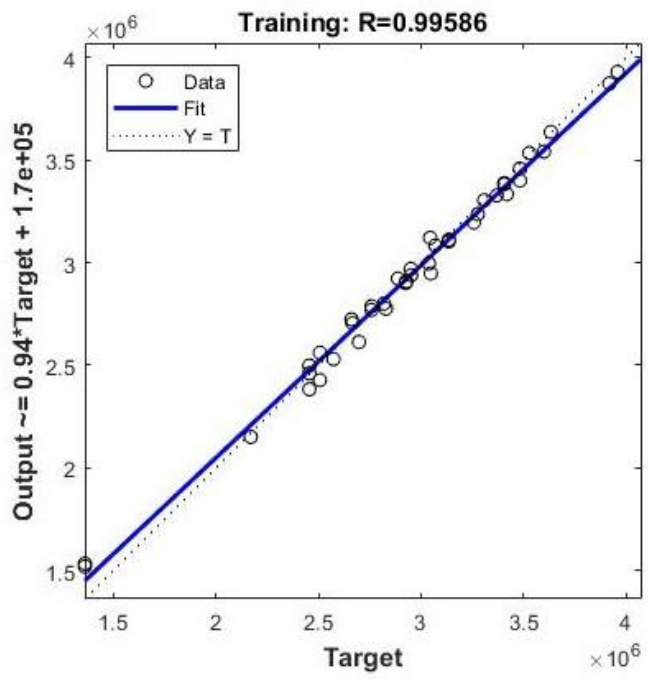

Figure 13. Training data performance

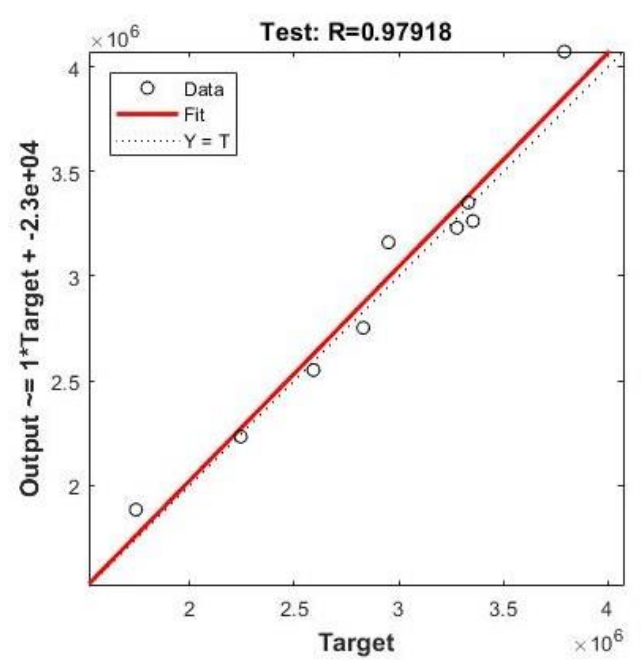

Figure 14. Test data performance

Margin of Deviation $=\left[\frac{\mathrm{W}_{\mathrm{exp}}-\mathrm{W}_{\mathrm{ANN}}}{\mathrm{W}_{\exp }}\right] \times 100 \%$

The electricity generation values of the cogeneration power plant were compared according to the number of data obtained by using an ANN. The comparison was performed separately for three different data sets used in the development of the ANN. 


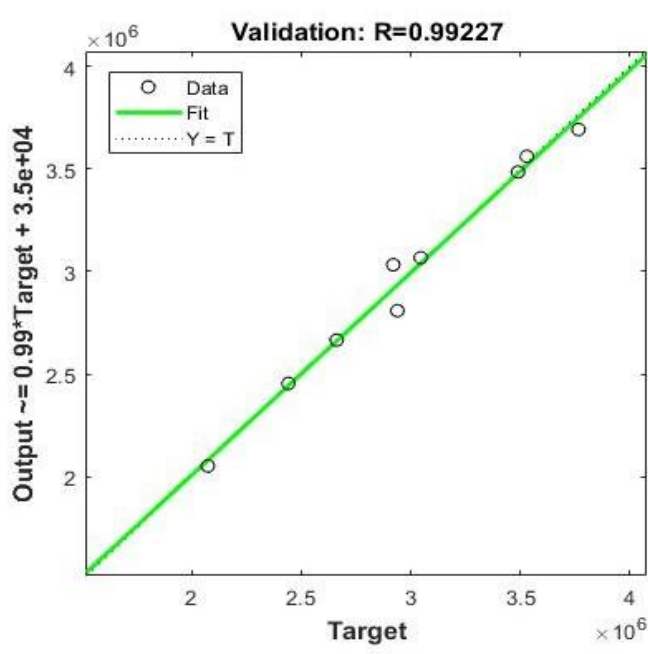

Figure 15. Validation Data Performance

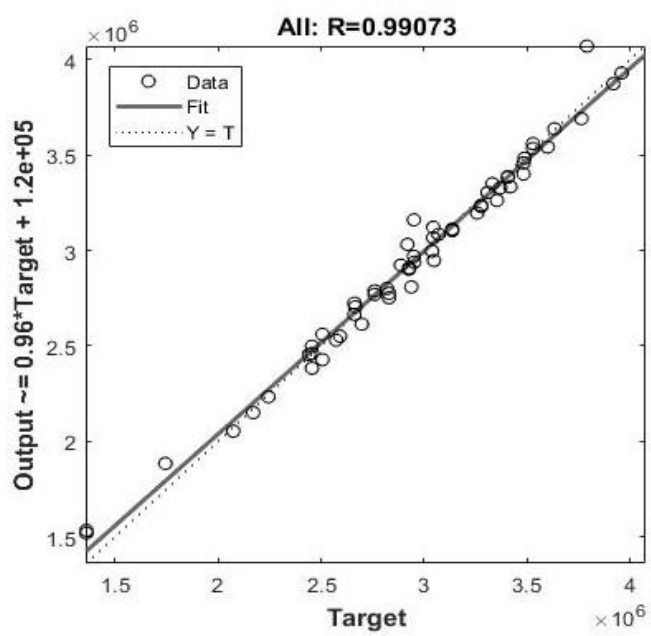

Figure 16. General performance

As can be seen in Figure 20, the estimated values using the ANN and the production values of the cogeneration power plant are very close to each other. It means that the ratio between the values estimated by the ANN and the production values of the cogeneration power plant is acceptable. In Figure 21, error rates of electrical energy generation values estimated using the ANN are shown based on the number of data. Determination of error rates is one of the studies conducted to evaluate the performance of the ANN model whose training phase has been completed. The amount of deviation between the electrical energy generation values of the cogeneration power plant and the data obtained from the ANN was calculated using Equation (6).

The calculated deviation amounts are shown in separate graphs for each training, test and validation data set used in the ANN. As can be seen in Figure 21, the production values predicted by the ANN are very close to the zero line and the deviation amounts are very low and acceptable. These error rates indicate that the results obtained from the ANN are accurate with acceptable deviation rates. As can be seen in the three-dimensional graph given in Figure 22, the ANN was able to estimate the electrical energy generation values of the cogeneration power plant in the range of $-5.34 \%$ to $2.57 \%$ with an average deviation of $-0.61 \%$. In the graph, the intensity of the zero error area indicated by the green region is an expression of the good agreement between experimental results and ANN outputs.

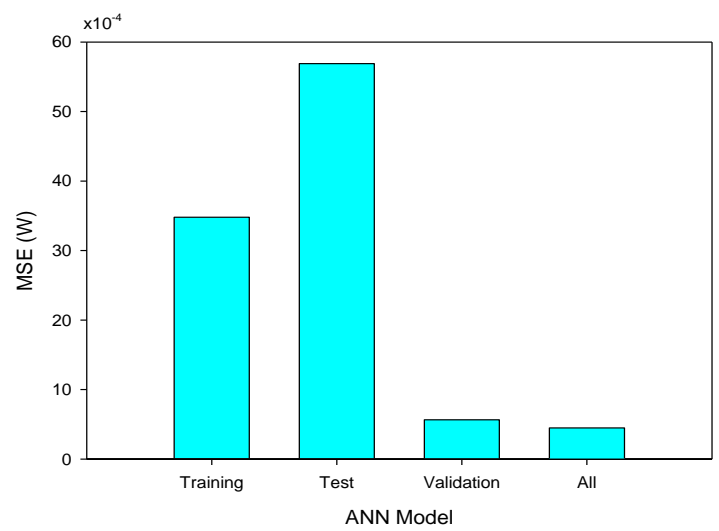

Figure 17. Mean square error values for training, validation, test, and all data

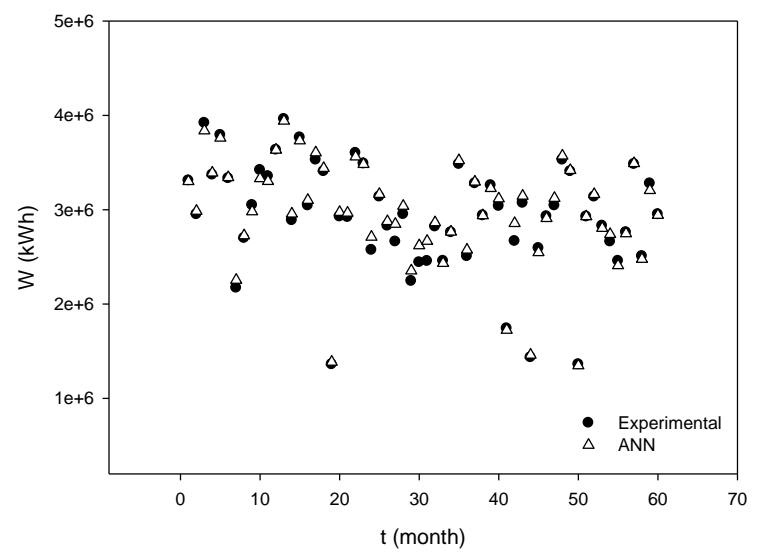

Figure 18. Comparison of production values with ANN outputs

Comprehensive studies have been carried out on the energy and exergy analysis of this cogeneration power plant, where electricity energy generation values are predicted using ANNs $[57,61]$.

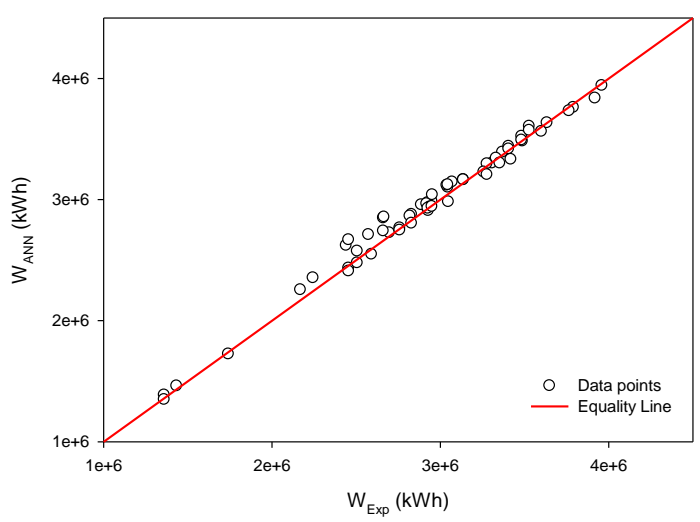

Figure 19. Comparison of experimental production data with artificial neural network data 

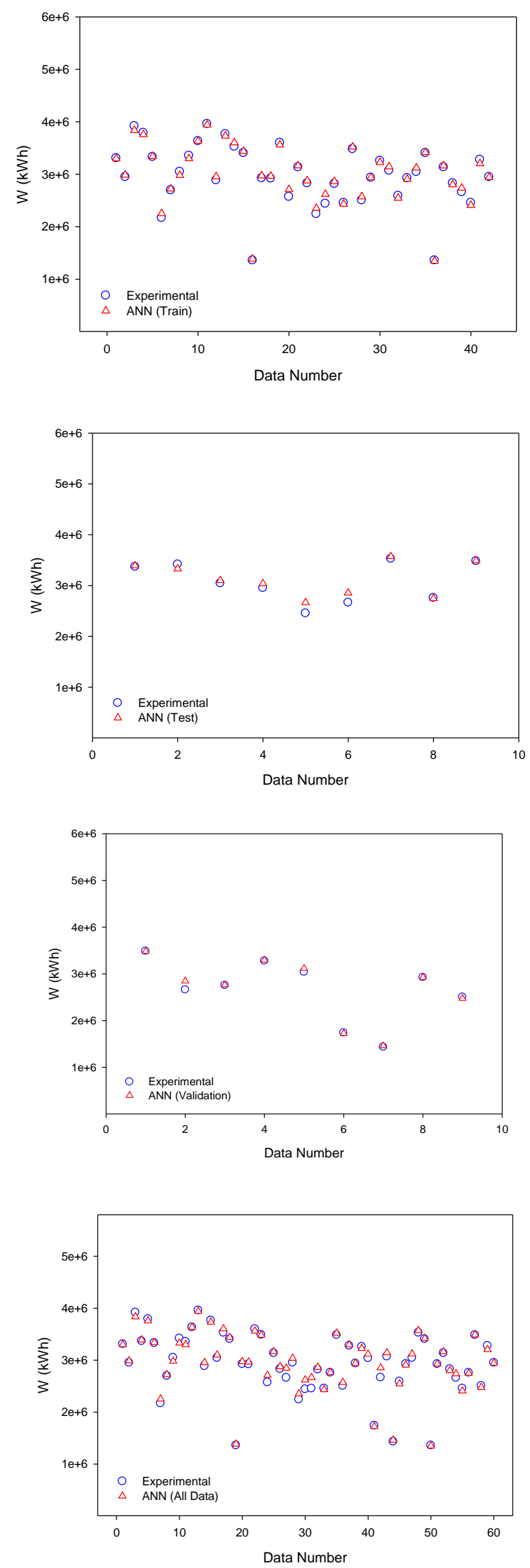

Figure 20. Comparison of $\mathrm{ANN}$ and plant production values according to data number
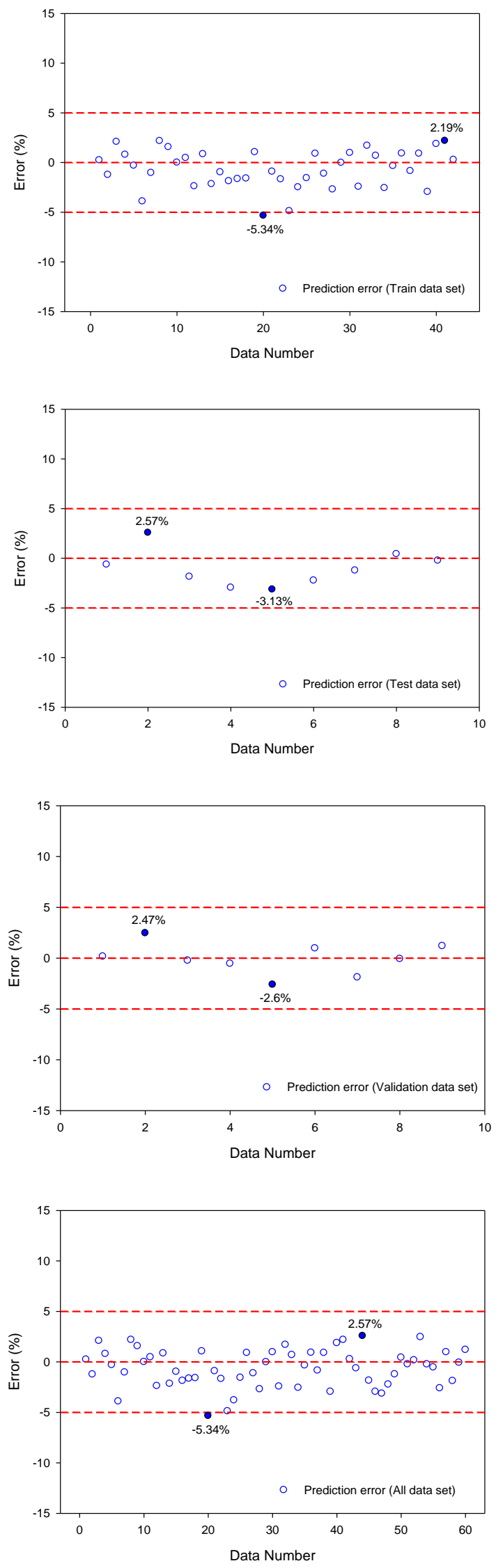

Figure 21. Prediction error by ANN according to data number 


\section{Conclusion}

Numerous studies on cogeneration power plants in the literature have focused on the efficiency and exergy analysis of cogeneration power plants, while various optimization studies with ANNs are also available. In this study, in order to estimate the electricity generation values of a 12-cylinder $32 / 40$ type diesel engine cogeneration power plant operating with heavy fuel oil, a multi-layer perception forward-feed backpropagation ANN was developed through the Levenberg-Marquardt algorithm.

In the ANN model, time (t), working hours (h), fuel consumption $(\mathrm{m})$ and power plant internal consumption $\left(\mathrm{W}_{\mathrm{p}}\right)$ are defined as input variables, and the electricity generation values $(\mathrm{W})$ of the cogeneration power plant are estimated based on these four input values.

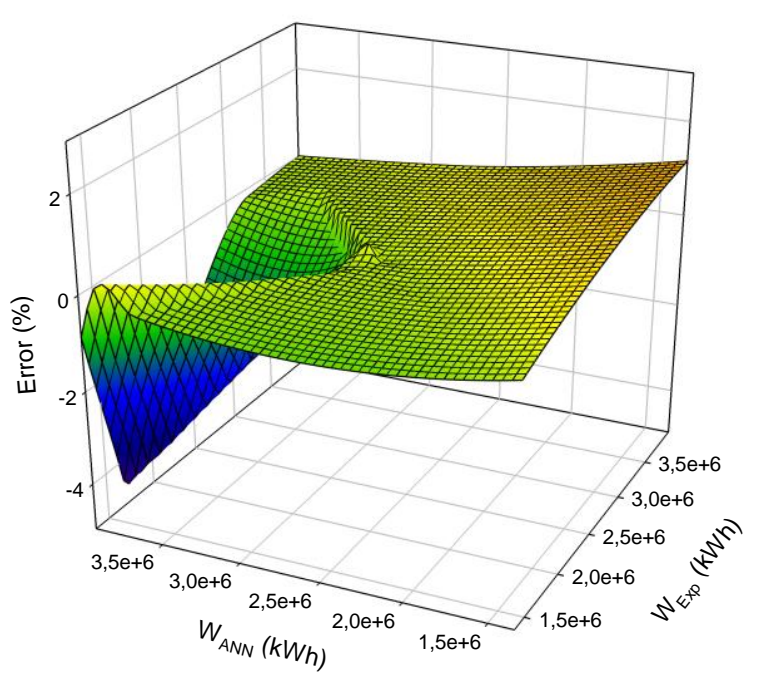

Figure 22. Deviation rates of experimental and ANN data

The ANN was designed using the 5-year (60 months) data of the cogeneration power plant. $42(70 \%)$ data were used for training, $9(15 \%)$ were used for validation, and 9 $(15 \%)$ were used for testing. The obtained results showed that the R-value obtained for the ANN is 0.99073, The mean error square value is $4.734 \mathrm{e}-8$, and the ANN is modeled optimally. The ANN was able to estimate the electrical energy generation values of the cogeneration power plant in the range of $-5.34 \%$ to $2.57 \%$ and with an average error margin of $-0.61 \%$. In the future, different estimation and optimization studies of cogeneration power plants can be made by using ANNs.

\section{Acknowledgements}

The author would like to thank the management of the BIRKO factory for their cooperation and supply of data during this study.

\section{Conflict of interest statement}

The author declares that there is no conflict of interest.

Similarity Rate: $19 \%$.

\section{Nomenclature}

$\begin{array}{ll}\text { AI } & \text { Artificial Intelligence } \\ \text { ANN } & \text { Artificial Neural Network } \\ \text { b } & \text { Bias } \\ \text { BS\&W } & \text { Basic Sediment and Water } \\ \text { BTU } & \text { British Thermal Unit } \\ \text { CHP } & \text { Combined Heat and Power } \\ \text { CT } & \text { Cooling Tower } \\ \text { f } & \text { Transfer Function } \\ \text { FF-BP } & \text { Feed Forward Back Propagation } \\ \text { h } & \text { Working hour (h) } \\ \text { H } & \text { Hydrogen } \\ \text { HE } & \text { Heat Exchanger } \\ \text { HT } & \text { High Temperature } \\ \text { HHV } & \text { Higher Heating Values } \\ \text { IEA } & \text { International Energy Agency } \\ \text { LT } & \text { Low Temperature } \\ \text { MLP } & \text { Multi-layer perception } \\ \text { MSE } & \text { Mean Square Error } \\ \text { S } & \text { Sulphite } \\ \text { t } & \text { Time period (month) } \\ \text { m } & \text { Fuel Consumption (kg) } \\ \text { w } & \text { weights } \\ \text { W } & \text { Power generation of power plant }(\mathrm{kWh}) \\ \text { W } & \text { Internal power consumption (kWh) } \\ & \end{array}$

\section{References}

[1] International Energy Agency, World energy outlook. ISBN: 978-92-6420805-6. 2014.

[2] S.D. Oh, H.S. Pang, S.M. Kim and H.Y. Kwak, Exergy analysis for a gas turbine cogeneration system. J Eng GasTurboPower,118:78291,1996.https://doi.org/10.11 $15 / 1.2816994$

[3] Nato, 3rd World Countries Cogeneration Case Studies, 2001.

[4] Energy Nexus Group, Technology characterization: reciprocating engines, Environmental Protection Agency Climate Protection Partnership Division, Washington DC, 2002.

[5] R. Benelmir and M. Feidt, Energy cogeneration systems and energy management strategy, Energy Conversion and Management 39, 1791-1802, 1998. https://doi.org/10.1016/S0196-8904(98)00055-7

[6] J.A. Orlando, Cogeneration design guide. USA: ASHRAE, Inc; 1996.

[7] C.A. Frangopoulos, EDUCOGEN, The European educational tools on cogeneration. European Commission. December 2001.

[8] Small-scale cogeneration, why? In which case? A guide for decision makers. European Commission, Directorate General for Energy DGXVII; July; 1999.

[9] R. Benelmir and M. Feidt, Energy cogeneration systems and energy management strategy. Energy Convers Manage 39(16-18), 1791-802, 1998. https://doi.org/10.1016/S0196-8904(98)00055-7

[10] B.W. Wilkinson and R.W. Barnes, Cogeneration of electricity and useful heat. CRC Press Inc.; 1980.

[11] G. Major, Small scale cogeneration. The Netherlands: Centre for the Analysis and Dissemination of 
Demonstrated Energy Technologies. CADDET Energy Efficiency Analysis Series 1. IEA/OECD; 1995.

[12] M. Kanoglu. and İ. Dincer, Performance assessment of cogeneration plants, Energy Conversion and Management, 50, 76-81, 2008. https://doi.org/10.1016/ j.enconman.2008.08.029

[13] J. Kartano, Power plant business. Wartsila NSD, Finland; 2002.

[14] A. Abusoglu and M. Kanoglu, Exergetic and thermoeconomic analyses of diesel engine powered cogeneration: Part 2 - Application, Applied Thermal Engineering 29, 242-249, 2009.

[15] M.A. Rosen, Energy- and exergy-based comparison of coal-fired and nuclear steam power plants. Exergy: Int J;1(3),180-92, 2001. https://doi.org/10.1016/S11640235(01)00024-3

[16] M.A. Rosen, M.N. Le and İ. Dincer, Efficiency analysis of a cogeneration and district energy system. Appl Thermal Eng, 25, 147-59, 2005. https://doi.org/ 10.1016/j.applthermaleng.2004.05.008

[17] L. Ozgener, A. Hepbasli and İ. Dincer, Performance investigation of two geothermal district heating systems for building applications: energy analysis. EnergyBuild, 38(4), 286-92. 2006. https://doi.org/ 10.1016/ j.enbuild.2005.06.021

[18] M.A. Rosen, Reductions in energy use and environmental emissions achievable with utility-based cogeneration: simplified illustrations for Ontario. Appl Energy;61:163-74, 1998.

[19] C.D. Rakopoulos and E.G. Giakoumis, Simulation and exergy analysis of transient diesel engine operation. Energy, 22(9), 875-85, 1997. https://doi.org/ 10.1016/S0360-5442(97)00017-0

[20] K. Nakonieczny, Entropy generation in a diesel engine turbocharging system. Energy, 27:1027-56, 2002.

[21] C.Y. Lin, Reduction of particulate matter and gaseous emission from marine diesel engines using a catalyzed particulate filter. Ocean Eng, 29, 1327-41, 2002.

[22] A. Parlak, H. Yasar and B. Sahin, Performance and exhaust emission characteristics of a lower compression ratio LHR diesel engine. Energy Conversion Management 44, 163-75. 2003. https://doi.org/10.1016/S01968904(01)00201-1

[23] C.M. Nam and B.M. Gibbs, Application of the thermal DeNOx process to diesel engine DeNOx: An experimental and kinetic modeling study. Fuel 81, 1359-67, 2002.

[24] Y. Ust, B. Sahin and T. Yilmaz, Optimization of a regenerative gas-turbine cogeneration system based on a new exergetic performance criterion:exergetic performance coefficient. Proc Institut Mech Engineers A - J Power Energy, 221(A4), 447-57, 2007. https://doi.org/10.1243/09576509JPE379

[25] I.S. Ertesva, Exergetic comparison of efficiency indicators for combined heat and power (CHP). Energy, 32, 2038-50, 2007.

[26] A. Khaliq and T.A. Khan, Energetic and exergetic efficiency analysis of an indirect fired air-turbine combined heat and power system. Int J Exergy, 4(1), 38-53,2007.https://doi.org/10.1504/IJEX.2007.011578

[27] G. Bidini, U. Desideri, S. Saetta and P.P. Bacchini, Internal combustion engine combined heat and power plants: Case study of the University of Perugia power plant. Appl Thermal Eng, 18, 401-12, 1998.

[28] A. Castillo, Risk analysis and management in power outage and restoration: a literature survey. Electr Power Syst.Res.107:9-15, 2014. https://doi.org/10.1016/ j.epsr.2013.09.002

[29] J.H. Lee, T.S. Kim and E.H. Kim, Prediction of power generation capacity of a gas turbine combined cycle cogeneration plant, Energy 124, 187-197, 2017.

[30] I.H. Witten and E. Frank, Data mining : practical machine learning tools and techniques. second ed. CA: MORGAN Kaufmann Publisher; p. 4-9, 2005.

[31] Y. Song, C.W. Gu and X.X. Ji, Development and validation of a full-range performance analysis model for a three-spool gas turbine with turbine cooling. Energy, 89, 545-57, 2015. https://doi.org/10.1016/ j.energy.2015.06.015

[32] J. Duan, L. Sun, G. Wang and F. Wu, Nonlinear modeling of regenerative cycle micro gas turbine. Energy, 91, 168-75, 2015.

[33] Li YG. Gas turbine performance and health status estimation using adaptive gas path analysis. J Eng Gas Turbines Power, 041701, 132, 2010. https://doi.org/ 10.1115/1.3159378

[34] J. Smrekar, D. Pandit, M. Fast, M. Assadi and S. De, Prediction of power output of a coal-fired power plant by artificial neural network. Neural Comput Appl, 19, 725-40, 2009. https://doi.org/10.1007/s00521-0090331-6

[35] Y. Tunckaya and E. Koklukaya, Comparative prediction analysis of $600 \mathrm{MWe}$ coal fired power plant production rate using statistical and neural-based models. J Energy Inst, 88, 11-8, 2015.

[36] S.Z. Boksteen, J.P. Van Buijtenen, R. Pecnik and D. Van Der Vecht, Bayesian calibration of power plant models for accurate performance prediction. Energy Convers. Manag. , 83, 3, 14-24, 2014. https://doi.org/ 10.1016/ j.enconman.2014.03.073

[37] P. Tüfekci, Prediction of full load electrical power output of a base load operated combined cycle power plant using machine learning methods. Int J Electr Power Energy Syst, 60, 126-40, 2014.

[38] F. Hajabdollahi, Z. Hajabdollahi, and H. Hajabdollahi, Soft computing based multi-objective optimization of steam cycle power plant using NSGA-II and ANN. Applied Soft Computing, 12, 3648-55, 2012.

[39] O. Arslan, Power generation from medium temperature geothermal resources: ANN-based optimization of Kalina cycle system-34. Energy, 36, 2528-34, 2011. https://doi.org/10.1016/j.energy.2011.01.045

[40] M.V. J.J. Suresh, K.S. Reddy, and A.K. Kolar, ANNGA based optimization of a high ash coal-fired supercritical power plant. Applied Energy, 88, 674873, 2011. 
[41] M.M. Rashidi, N. Galanis, F. Nazari, A. Basiri Parsa, and L. Shamekhi, Parametric analysis and optimization of regenerative Clausius and organic Rankine cycles with two feedwater heaters using artificial bees colony and artificial neural network. Energy, 36, 5728-40, 2011.

[42] P. Olausson, D. Häggståhl, J. Arriagada, E. Dahlquist and M. Assadi, Hybrid model of an evaporative gas turbine power plant utilizing physical models and artificial neural network. Proceedings of the ASME Turbo Expo. (2003) Atlanta, Georgia, USA., 2003. https://doi.org/10.1115/GT2003-38116

[43] S. De, M. Kaiadi, M. Fast and M. Assadi, Development of an artificial neural network model for the steam process of a coal biomass co-fired combined heat and power (CHP) plant in Sweden. Energy, 32, 2099-2109, 2007.

[44] T. Bekat, M. Erdogan, F. Inal, and A. Genc, Prediction of the bottom ash formed in a coal-fired power plant using artificial neural networks. Energy, 45 882-7, 2012. https://doi.org/10.1016/j.energy.2012.06.075

[45] J. Ma, B.-S. Wang and Y.-G. Ma, ANN-based real-time parameter optimization via GA for superheater model in power plant simulator. Proceedings of the 7 th International Conference on Machine Learning and Cybernetics, ICMLC, 4, 2269-73, 2008.

[46] X. Du, L. Liu, X. Xi, L. Yang, Y. Yang, Z. Liu, Back pressure prediction of the direct air cooled power generating unit using the artificial neural network model. Applied Thermal Engineering, 31, 3009-14. 2011.https://doi.org/10.1016/j.applthermaleng.2011.05 .034

[47] L. Pan, D. Flynn and M. Cregan, Statistical model for power plants performance monitoring and analysis. Universities Power Engineering Conference, UPEC 2007, 121-126. 42nd International Conference. 2007.

[48] S. Lu and B.W. Hogg, Dynamic and nonlinear modelling of power plant by physical principles and neural networks. International Journal of Electrical Power \& Energy Systems, 22, 67-78, 2000. https://doi.org/10.1016/S0142-0615(99)00036-8

[49] F. Fantozzi and U. Desideri, Simulation of power plant transients with artificial neural networks: application to an existing combined cycle. Proceedings of the Institution of Mechanical Engineers Part A, 212, 299313, 1998.

[50] S. Tronci, R. Baratti and A. Servida, Monitoring pollutant emissions in a $4.8 \mathrm{MW}$ power plant through neural network. Neurocomputing, 43, 3-15, 2002. https://doi.org/10.1016/S0925-2312(01)00617-8
[51] D. Flynn, J. Ritchie and M. Cregan, Data mining techniques applied to power plant performance monitoring. Paper presented at IFAC world congress, Prague, 2005.

[52] C.E. Romero and J. Shan, Development of an artificial neural network-based software for prediction of power plant canal water discharge temperature. Expert Systems with Applications, 29, 831-838, 2005. https://doi.org/10.1016/j.eswa.2005.06.009

[53] C.-T. Hsu, H.-J. Chuang and C.-S. Chen, Adaptive load shedding for an industrial petroleum cogeneration system. Expert Systems with Applications, 38 13967974, 2011. https://doi.org/10.1016/j.eswa.2011.04.204

[54] M. Moghavvemi, S.S. Yang and M.A. Kashem, A practical neural network approach for power generation automation. Proceedings of Energy Management and Power Delivery. 1998 International Conference, 1, 305-310, 1998.

[55] A.B. Çolak, O. Yıldız, M. Bayrak and B.S. Tezekici, Experimental study for predicting the specific heat of water based $\mathrm{Cu}-\mathrm{Al}_{2} \mathrm{O}_{3}$ hybrid nanofluid using artificial neural network and proposing new correlation, International Journal of Energy Research, 1-18, 2020. https://doi.org/10.1002/er.5417

[56] MAN, 32/40 Project Guide - Stationary Four-stroke diesel engines, version 1.5, 2013.

[57] M. Bayrak and A. Gungor, Fossil fuel sustainability: Exergy assessment of a cogeneration system, Int. J. Energy Res, 35, 162-68, 2011. https://doi.org/ 10.1002/er.1759

[58] M.H. Esfe, M. Reiszadeh, S. Esfandeh and M. Afrand, Optimization of MWCNTs (10\%) - Al2O3 (90\%)/5W50 nanofluid viscosity using experimental data and artificial neural network, Physica A 512, 731744, 2018.

[59] A.B. Çolak, An experimental study on the comparative analysis of the effect of the number of data on the error rates of artificial neural networks, International Journal of Energy Research, 2020. https://doi.org/10.1002/ er.5680

[60] H. Khodadadi, D. Toghraie and A. Karimipour, Effects of nanoparticles to present a statistical model for the viscosity of $\mathrm{MgO}-W$ ater nanofluid, Powder Technology, 342, 166-180, 2019. https://doi.org/10.1016/j.powtec.2018.09.076

[61] M. Bayrak and A. Gungor, Efficiency assessment of a cogeneration system, International Journal of the Physical Sciences 6(28), 6439-49, 2011. https://doi.org/10.5897/IJPS10.418 